\title{
Implementasi Metode MVC untuk Pembangunan Sistem Informasi Pelatihan Kerja: Studi Kasus UPT Pelatihan Kerja Singosari
}

\author{
Usman Nurhasan ${ }^{1}$, Betlian Fajrin², Defandy Fanny A $^{3}$, Fredo Vale Yuda Ughay ${ }^{4}$ \\ Jurusan Teknologi Informasi \\ Politeknik Negeri Malang \\ Malang, Indonesia \\ e-mail: ${ }^{1}$ usmannurhasan@ @ polinema.ac.id, ${ }^{2}$ fajrinbetlian@gmail.com, ${ }^{3}$ defandydefan@gmail.com, \\ ${ }^{4}$ fredovale@gmail.com
}

Diajukan: 13 Mei 2019; Direvisi: 6 Mei 2020; Diterima: 11 Juni 2020

\begin{abstract}
Abstrak
UPT Pelatihan Kerja Singosari adalah lembaga pemerintah provinsi Jawa Timur sebagai penyelenggara pelatihan untuk memberikan sarana prasarana pendidikan dan sebuah informasi lowongan pekerjaan pada sebuah perusahaan agar masyarakat mampu menghadapi dunia kerja dan cepat menerima sebuah informasi kerja. Dalam Divisi Pengembangan dan Pemasaran, dilakukan berbagai macam proses yang salah satu tujuannya adalah memberikan informasi kepada masyarakat mengenai lowongan pekerjaan, lowongan pelatihan, dan lain sebagainya. Akan tetapi, proses pemberian informasi pelatihan serta pendaftaran masih dilakukan secara manual, sehingga masyarakat yang tinggal jauh dari lokasi pelatihan kesulitan menerima informasi secara langsung. Dengan diciptakan sebuah sistem informasi berbasis website, diharapkan masyarakat luas dapat menjangkau dengan mudah berbagai informasi pelatihan yang diberikan oleh UPT Pelatihan Kerja Singosari karena dapat dilakukan kapan pun dan di mana pun. Pembuatan sistem informasi berbasis website ini menggunakan framework CodeIgniter dan juga metode Model View Controller (MVC) karena pada penelitian sebelumnya mampu membuat sistem lebih stabil dan mudah dilakukan perbaikan. Hasil dari penelitian ini adalah masyarakat menjadi lebih terbantu dengan adanya sistem ini karena tidak perlu jauh-jauh untuk melihat informasi yang mereka butuhkan.
\end{abstract}

Kata kunci: Informasi, Sistem informasi, Website, CodeIgniter, Model View Controller.

\section{UPT Pelatihan Kerja Singosari is an East Java government institutions that offered a training} facility and giving a lot of information about job vacancy of a company. UPT Pelatihan Kerja Singosari structure is consist of some different divisions which one of them is managing activity to develop and markets UPT Pelatihan Kerja Singosari. Development and Marketing division, did many process which one of them is giving an information to people about job vacancy, training information, and many others. However, the process of providing training information and registration is still done manually, so that people who live far from the training location have difficulty of receiving information directly. By creating a website-based information system, it is hoped that the people can easily get training information provided by the UPT Pelatihan Kerja Singosari because it can be done anytime and anywhere. Making this websitebased information system uses a CodeIgniter framework and also the Model View Controller (MVC) method because in previous studies it was able to make the system more stable and easier to do repairs. The results of this study are that the people is more helped by the existence of this system because it does not need to go far to see the information they need.

Keywords: Information, Information system, Website, CodeIgniter, Model View Controller.

\section{Pendahuluan}

UPT Pelatihan Kerja Singosari adalah lembaga pemerintah provinsi Jawa Timur sebagai penyelenggara pelatihan untuk memberikan sarana prasarana pendidikan dan sebuah informasi lowongan pekerjaan pada sebuah perusahaan agar masyarakat mampu menghadapi dunia kerja dan cepat menerima 
sebuah informasi kerja. Struktur UPT Pelatihan Kerja Singosari terdiri dari beberapa divisi, salah satunya Divisi Pengembangan dan Pemasaran. Divisi ini merupakan divisi yang membawahi aktivitas untuk mengembangkan dan memasarkan UPT Pelatihan Kerja Singosari. Dalam Divisi Pengembangan dan Pemasaran, dilakukan berbagai macam proses yang salah satu tujuannya adalah untuk menarik dan atau menambah calon peserta pelatihan pada UPT PK Singosari.

Akan tetapi dalam prosesnya, pemberian informasi masih menggunakan cara yang manual. Seorang penerima informasi atau masyarakat harus mendatangi UPT Pelatihan Kerja Singosari untuk mendapatkan informasi secara langsung. Hal ini tentu saja akan membuat masyarakat yang memiliki tempat tinggal jauh akan merasa kesulitan untuk mendapatkan informasi. Tentunya ini juga akan berdampak kepada berkurangnya daya tarik calon peserta pelatihan dan pencari pekerjaan untuk menggali informasi lebih dalam di UPT Pelatihan Kerja Singosari. Oleh karena itu untuk dapat menambah daya tarik calon peserta pelatihan, maka dibuatlah sebuah sistem informasi berbasis website dan video profile mengenai kegiatan-kegiatan yang dilakukan dan fasilitas-fasilitas untuk mendukung kegiatan dari para peserta pelatihan di UPT PK Singosari.

Berdasarkan penelitian sebelumnya, disebutkan bahwa penggunaan metode MVC berhasil meningkatkan stabilitas dan reusabilitas sistem. Di samping itu juga memudahkan para pengelola untuk memperbaiki jika ada perubahan alur script atau perbaikan script [1]. Oleh karena itu maka penulis juga menerapkan metode yang sama guna mendapatkan hasil yang sesuai dengan keinginan penulis.

Berdasarkan masalah yang terjadi kami membuat sebuah penelitian yang bertujuan dapat menampung informasi-informasi yang akan diberikan kepada masyarakat. Dalam website tersebut, terdapat berbagai informasi yang dibutuhkan dan menarik bagi khalayak agar muncul daya tarik mengikuti program pelatihan di UPT PK Singosari. Selain itu juga, terdapat fitur formulir yang dapat diisi dan dicetak oleh calon peserta pelatihan agar mereka tidak perlu datang ke kantor hanya untuk mengambil formulir yang digunakan untuk mendaftar mengikuti program pelatihan.

\section{Metode Penelitian}

\subsection{Pengumpulan Data}

Dalam mengumpulkan data, teknik pengumpulan data yang digunakan dalam penelitian ini ada 3 yaitu:

\section{a. Studi Pustaka}

Dalam pengembangan website ini dilakukan pengumpulan data dan informasi yang dibutuhkan dalam pembuatan sistem informasi berbasis website ini. Data dan informasi tersebut bersumber pada buku-buku, laporan, dan sumber lainnya.

b. Observasi

Observasi dilakukan dengan mengamati dan mengumpulkan data dan informasi yang dibutuhkan dengan melakukan pengamatan pada lingkungan UPT Pelatihan Kerja Singosari.

c. Wawancara

Wawancara dilakukan dengan melakukan kegiatan tanya jawab dan menggali informasi terhadap staf pada divisi pengembangan dan pemasaran agar mendapatkan informasi yang diperlukan.

\subsection{Perancangan Sistem}

Setelah data diperoleh, maka dilakukan analisis dan perancangan sistem sesuai dengan spesifikasi dan kebutuhan sistem. Perancangan sistem dapat digambarkan sebagai berikut:

\section{a. Work Breakdown Structure}

Work breakdown structure (WBS) adalah suatu penggolongan komponen-komponen atau struktur kerja yang digambarkan ke dalam bentuk grafik sehingga dapat mengatur dan membagi berdasarkan kelompok kerja [2][3]. Untuk mengembangkan sistem ini dibuat sebuah Work Breakdown Structure (WBS) agar dapat menggambarkan struktur pengerjaan sistem. Work Breakdown Structure dari sistem informasi pendaftaran ini dapat digambarkan sebagai berikut: 


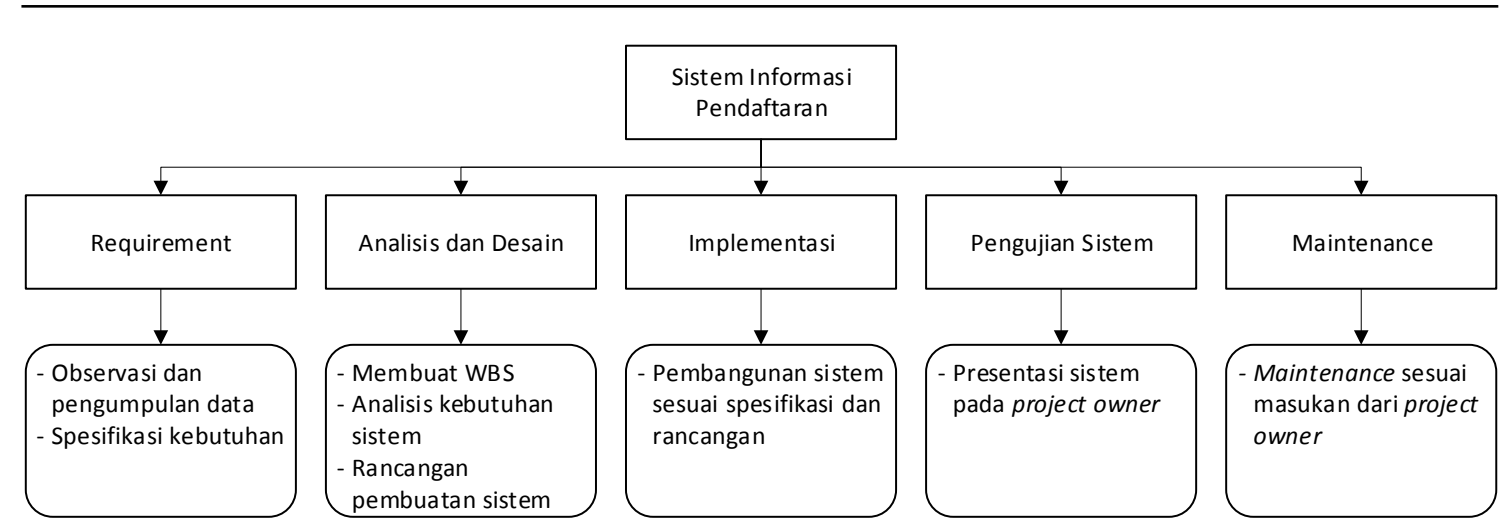

Gambar 1. Work Breakdown Structure.

1. Requirement

Merupakan tahapan interaksi antara pihak client atau pengguna sistem dan juga pihak pengembang sistem. Dalam tahap ini di gambarkan secara detail informasi dan spesifikasi seperti apa yang di inginkan oleh pengguna. Informasi yang diberikan antara pihak client dan pihak pengembang sistem harus diberikan secara detail agar tidak terjadi kesalahpahaman dan perbedaan sudut pandang dalam mengembangkan aplikasi yang ingin dibuat. Dalam hal ini peneliti melakukan survei terhadap keinginan dan kebutuhan dari pihak UPT PK Singosari untuk melakukan pembuatan website sistem informasi agar sesuai dengan tujuan yang ingin dicapai pihak UPT PK Singosari.

2. Analisis dan Desain

Analisis merupakan tahap penjabaran dari sebuah sistem informasi yang utuh menjadi beberapa komponen agar dapat teridentifikasi permasalahan dan hambatan yang terjadi sehingga kebutuhan dapat diketahui langkah-langkah atau proses perbaikannya [4]. Tahap analisis sistem dilakukan sebelum masuk ke dalam desain sistem, karena tahap analisis merupakan salah satu tahap yang kritis dan penting. Pada tahap ini, jika terjadi sebuah kesalahan maka akan berdampak pada tahap-tahap selanjutnya. Desain perangkat lunak merupakan proses yang mengacu pada desain pembuatan program meliputi struktur data, arsitektur, user interface, dan prosedur pengodean. Tahap ini merupakan tahap transformasi dari sebuah analisis kebutuhan menjadi representasi desain sehingga dapat digunakan sebagai acuan pada tahap selanjutnya [5]. Dalam hal ini, kebutuhan dari pihak UPT PK Singosari serta tujuan yang telah dijabarkan sebelumnya pada tahapan requirement akan direpresentasikan oleh peneliti dalam bentuk desain website sistem informasi baik berupa user interface, struktur basis data, arsitektur software, dan lain sebagainya.

3. Implementasi

Implementasi dapat dikatakan sebagai proses dalam memastikan tercapainya sebuah kebijakan atau terlaksananya kebijakan tersebut. Selain itu, implementasi juga dapat diartikan sebagai penerapan dari tahap sebelumnya. Dalam hal ini hal-hal yang telah dirancang pada tahapan analisis dan desain akan diimplementasikan ke dalam website sistem informasi yang akan dibangun.

4. Pengujian Sistem

Pada tahap pengujian sistem dilakukan pengujian terhadap kebenaran program. Tahap ini dilakukan dengan melakukan pengujian pada semua bagian sistem dan memastikan apakah hasil yang berjalan apakah sudah sesuai dengan hasil yang diinginkan, dan akan dilakukan perbaikan jika terdapat kesalahan. Dalam hal ini website sistem informasi yang telah dibangun akan diuji baik dari segi fungsionalitasnya maupun parsing datanya. Maka akan diketahui apakah dapat berjalan dengan baik atau tidak.

5. Maintenance

Merupakan tahapan di mana admin yang diberi tugas dalam mengoperasikan sistem tersebut dapat memastikan sistem tetap mampu beroperasi dengan benar sesuai tujuan dan hasil yang diinginkan. Pemeliharaan sebuah perangkat lunak diperlukan karena perangkat lunak yang dikembangkan tidak berhenti sampai di situ saja, karena ketika program tersebut dijalankan masih memungkinkan terjadinya error kecil yang tidak ditemukan pada pengujian sebelumnya, ataupun ada penambahan beberapa fitur baru yang dapat ditambahkan pada perangkat lunak tersebut. Pengembangan diperlukan ketika adanya perubahan dari eksternal maupun internal perusahaan. 
Dalam hal ini website sistem informasi yang telah dibuat akan dicek apakah terdapat perubahan eksternal atau internal dari UPT PK Singosari.

\section{b. Use Case Diagram}

Use case diagram adalah penggambaran tentang alur sistem informasi yang akan dikembangkan. Use case diagram memiliki kegunaan untuk mengetahui fungsi-fungsi yang terdapat pada sistem informasi tersebut serta siapa saja aktor atau pengguna dari fungsi-fungsi tersebut [6]. Use case diagram merupakan gambaran grafis dari aktor, use case, dan interaksi yang menjelaskan alur dari suatu sistem. Use case diagram tidak menjelaskan secara detail mengenai penggunaan use case, tetapi hanya memberikan penggambaran secara singkat antara hubungan use case dan aktor dalam sebuah sistem [7]. Pada use case ini akan didapati fungsi-fungsi apa saja yang terdapat pada sistem yang akan dibuat. Syarat penamaan dalam use case ini adalah nama didefinisikan sesimpel mungkin dan dapat dipahami.

Di dalam use case, terdapat dua hal yang utama yaitu pendefinisian apa yang disebut use case dan juga aktor. Aktor adalah orang, proses, atau sistem lain yang memiliki interaksi terhadap sistem informasi yang akan dibuat. Sedangkan use case adalah fungsi-fungsi atau fitur apa saja yang terdapat dalam sistem sebagai unit-unit yang saling bertukar pesan antar unit atau aktor. Di dalam sistem informasi yang kami buat, use case yang kami buat memiliki dua aktor utama yaitu aktor yang berperan sebagai admin dan aktor yang berperan sebagai user [8].

Aktor yang berperan sebagai admin memiliki fungsi untuk mengolah data dan informasi baik menambah, mengubah, dan menghapus informasi tersebut. Sedangkan aktor yang berperan sebagai user dalam hal ini adalah sebagai penerima informasi. Kedua aktor ini akan saling berkaitan dalam proses pemberian dan penerimaan informasi. Pada Gambar 2 akan diberikan gambaran dari use case yang ada di dalam sistem informasi yang dibuat.

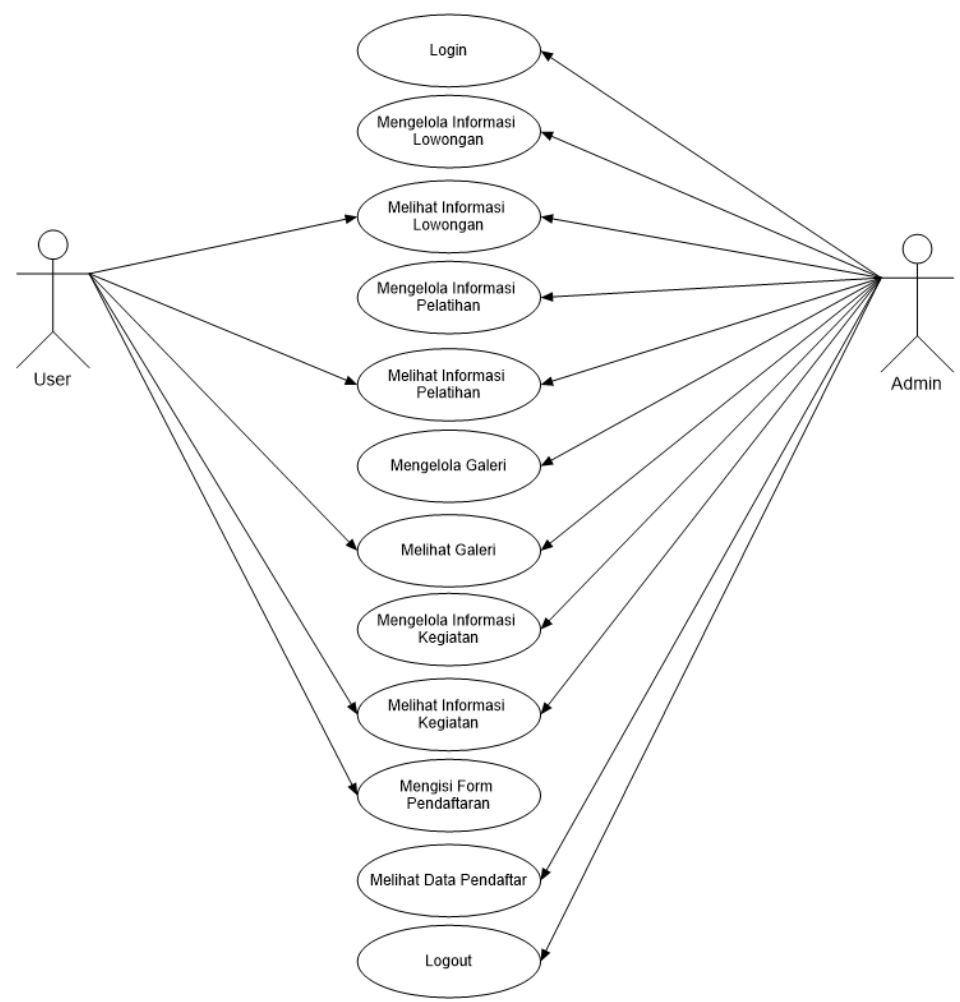

Gambar 2. Use case diagram.

Pada Gambar 2 menjelaskan tentang hubungan aktor dengan fitur-fitur yang ada pada sistem. Use case diagram tersebut dijelaskan pada use case description berikut: 
Tabel 1. Use case description.

\begin{tabular}{|c|c|c|}
\hline Use case & Aktor & Deskripsi \\
\hline Login & Admin & $\begin{array}{l}\text { Admin harus login terlebih dahulu sebelum mengakses sistem. Sehingga admin } \\
\text { dapat menggunakan semua fitur yang ada pada sistem. }\end{array}$ \\
\hline $\begin{array}{l}\text { Mengelola informasi } \\
\text { lowongan }\end{array}$ & Admin & $\begin{array}{l}\text { Admin dapat mengelola informasi lowongan yang akan ditampilkan pada } \\
\text { website. Admin dapat melakukan input data lowongan baru, mengedit data } \\
\text { lowongan dan menghapus data lowongan yang sudah kedaluwarsa. }\end{array}$ \\
\hline $\begin{array}{l}\text { Mengelola informasi } \\
\text { pelatihan }\end{array}$ & Admin & $\begin{array}{l}\text { Admin dapat mengelola informasi pelatihan yang akan ditampilkan pada website. } \\
\text { Admin dapat melakukan input data program pelatihan baru, mengedit data } \\
\text { program pelatihan dan menghapus data program pelatihan yang sudah ditutup } \\
\text { atau kuotanya sudah terpenuhi. }\end{array}$ \\
\hline Mengelola galeri & Admin & $\begin{array}{l}\text { Admin dapat mengelola gambar dari galeri yang akan ditampilkan pada website. } \\
\text { Admin dapat melakukan input gambar baru, mengedit keterangan dari gambar } \\
\text { dan menghapus gambar dari galeri. }\end{array}$ \\
\hline $\begin{array}{l}\text { Mengelola informasi } \\
\text { kegiatan }\end{array}$ & Admin & $\begin{array}{l}\text { Admin dapat mengelola informasi kegiatan yang akan ditampilkan pada website. } \\
\text { Admin dapat melakukan input data kegiatan baru, mengedit informasi kegiatan } \\
\text { dan menghapus data kegiatan. }\end{array}$ \\
\hline Melihat data pendaftar & Admin & $\begin{array}{l}\text { Admin dapat melihat jumlah serta keterangan atau data yang telah dimasukkan } \\
\text { oleh calon peserta pelatihan yang diisikan pada formulir pendaftaran. }\end{array}$ \\
\hline Melihat informasi lowongan & $\begin{array}{l}\text { Admin, } \\
\text { User }\end{array}$ & $\begin{array}{l}\text { Baik admin ataupun } u s e r \text {, keduanya dapat melihat informasi lowongan yang telah } \\
\text { ditampilkan di dalam website. }\end{array}$ \\
\hline Melihat informasi pelatihan & $\begin{array}{l}\text { Admin, } \\
\text { User }\end{array}$ & $\begin{array}{l}\text { Admin dan user, keduanya dapat melihat informasi pelatihan yang telah } \\
\text { ditampilkan di dalam website. }\end{array}$ \\
\hline Melihat galeri & $\begin{array}{l}\text { Admin, } \\
\text { User }\end{array}$ & $\begin{array}{l}\text { Admin dan } \text { user dapat melihat foto - foto kegiatan yang telah dilakukan oleh UPT } \\
\text { PK Singosari, baik kegiatan yang dilakukan di dalam maupun di luar lingkungan } \\
\text { UPT PK Singosari yang telah ditampilkan di dalam website. }\end{array}$ \\
\hline Melihat informasi kegiatan & $\begin{array}{l}\text { Admin, } \\
\text { User }\end{array}$ & $\begin{array}{l}\text { Admin dan user, keduanya dapat melihat informasi kegiatan yang telah } \\
\text { ditampilkan di dalam website. }\end{array}$ \\
\hline Mengisi formulir pendaftaran & User & $\begin{array}{l}\text { Formulir pendaftaran digunakan oleh calon peserta pelatihan yang ingin } \\
\text { mengikuti program pelatihan yang ada di UPT PK Singosari. }\end{array}$ \\
\hline
\end{tabular}

\subsection{Pengolahan Data}

Teknik analisis dan pengolahan data dilakukan dengan melakukan pengecekan data yang diperoleh dari hasil studi literatur, observasi, dan juga wawancara. Data yang telah tervalidasi tersebut nantinya akan diambil dan digunakan sebagai informasi yang mendukung dalam proses pembuatan sistem informasi berbasis website ini. Data yang diolah berupa data yang berkaitan dengan informasi pelatihan yang dikeluarkan oleh divisi pengembangan dan pemasaran SDM.

\subsection{Metode Pembangunan Sistem}

Metode yang digunakan dalam mengembangkan sistem ini adalah dengan menggunakan Framework CodeIgniter yang memiliki metode MVC. Model-View-Controller (MVC) merupakan suatu konsep yang pertama kali dikenalkan oleh penemu Smalltalk (Trygve Reenskaug) untuk membungkus suatu data bersama dengan proses pemodelan, proses pengolahan data pada controller dan tampilan atau view agar dapat digambarkan pada sebuah tampilan user [9]. Terdapat 3 jenis komponen dalam membangun suatu MVC, yaitu:

a. Model, memiliki hubungan dengan penggunaan database dalam melakukan pengolahan data (insert, update, delete, search) serta mengatur validasi dari bagian controller.

b. View, merupakan bagian yang mengatur tampilan yang akan diberikan pada user, pada suatu aplikasi web bagian ini biasanya berupa file yang diatur oleh controller. View memiliki peran agar dapat menerima dan menyajikan data kepada user dalam bentuk interface.

c. Controller, merupakan bagian yang mengelola hubungan antara bagian Model dan bagian View. Controller memiliki fungsi untuk mengatur request yang diterima dari user dan menentukan respons apa yang akan diberikan oleh aplikasi.

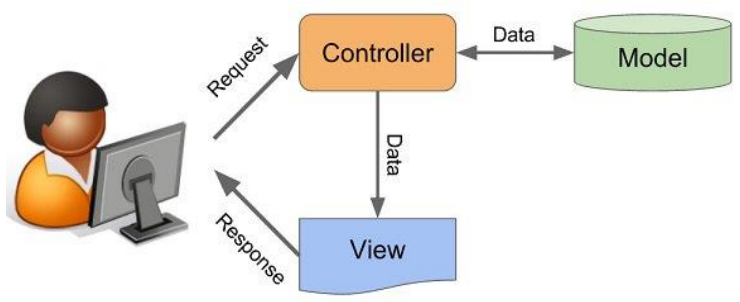

Gambar 3. Alur Model View Controller. 
Gambar 3 merupakan alur proses MVC. Ketika admin masuk terlebih dahulu harus login untuk dapat mengelola View manajemen admin tersendiri dan, kemudian masuk ke Model, berfungsi mengecek database dan mengembalikan database ketika berhasil atau gagal. Selanjutnya ke Controller, berfungsi mengambil atau mengelola request dari admin akan dikirimkan ke Model, kemudian Model ke View untuk menampilkan berhasil atau tidaknya.

\section{Hasil dan Pembahasan}

Untuk mempermudah proses pendaftaran dan pemberian informasi, maka dibuatlah sebuah sistem informasi berbasis website. Sistem informasi adalah sistem yang memiliki sebuah jaringan data yang saling terkoneksi satu sama lain sehingga data maupun informasi tersebut dapat berkomunikasi agar dapat digunakan dalam sistem organisasi data[10]. Website yang telah di buat memiliki beberapa menu yang dapat memudahkan pengguna terutama para calon peserta pelatihan yang hendak mengikuti program pelatihan di UPT PK Singosari.

Di dalam website ini terdapat menu info pelatihan yang menjabarkan mengenai program - program pelatihan yang akan di buka di UPT PK Singosari. Dengan adanya website ini user tidak perlu lagi jauhjauh datang ke lokasi UPT Pelatihan Kerja Singosari untuk mencari informasi dan melakukan pendaftaran. Dalam hal ini, terdapat 2 program pelatihan yang di buka di UPT PK Singosari, yaitu program APBN dan program APBD.

\subsection{Menampilkan Informasi Pelatihan}

Sebelum dilakukan pembuatan sistem informasi pendaftaran ini, proses pemberian informasi masih berjalan secara konvensional, yaitu dengan menempelkan informasi pada papan informasi. Hal ini membuat seseorang yang ingin melihat informasi tersebut harus datang langsung ke lokasi untuk melihat informasi tersebut. Dengan adanya sistem web ini dapat membuat pemberian informasi menjadi lebih efektif karena dapat secara langsung diakses melalui media internet.

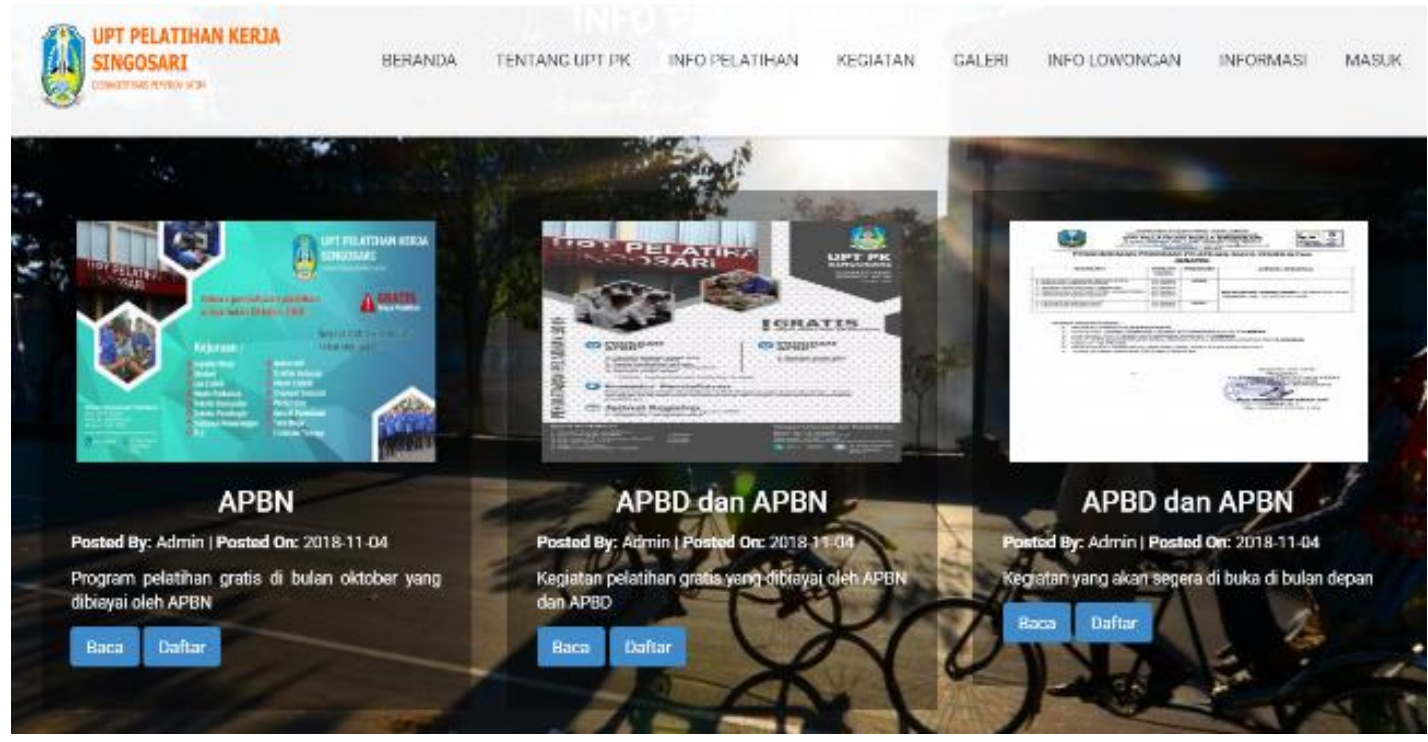

Gambar 4. Tampilan menu Informasi.

\subsection{Melakukan Pendaftaran Secara Online}

Dengan diberikan fasilitas untuk melihat informasi secara terbuka, maka para calon peserta pelatihan dapat dengan mudah mencari dan memahami program-program pelatihan yang ada, serta dapat menyesuaikan program pelatihan yang hendak diikuti. 


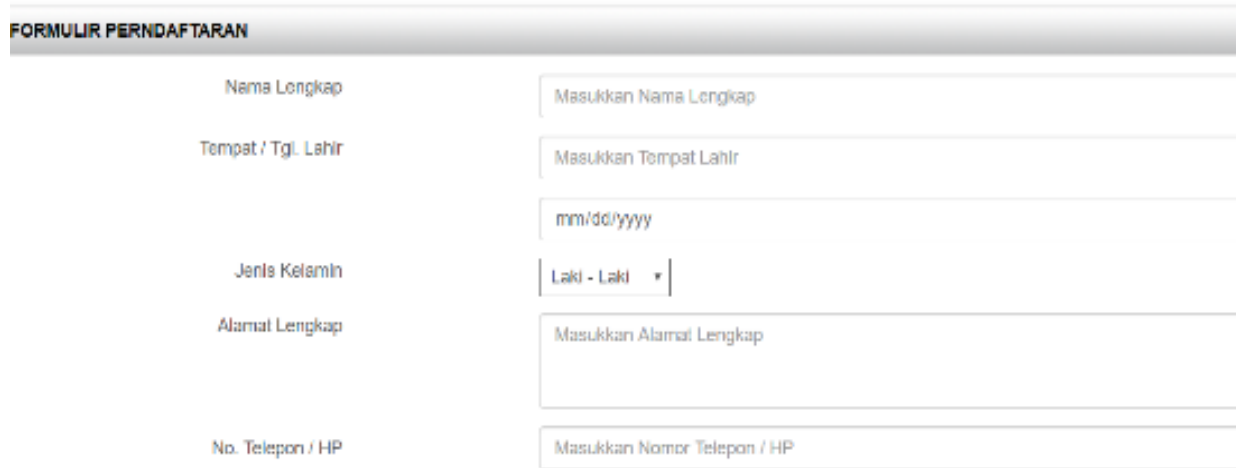

Gambar 5. Tampilan form Pendaftaran.

Pada Gambar 5, setelah menemukan program pelatihan yang sesuai, para calon peserta pelatihan tidak perlu datang ke kantor UPT PK Singosari secara langsung untuk melakukan pendaftaran. Di dalam website tersebut sudah disediakan formulir untuk program pelatihan agar para calon peserta pelatihan dapat langsung melakukan pendaftaran. Para calon peserta pelatihan yang hendak mendaftarkan diri harus melengkapi formulir yang terdapat di dalam website. Hal-hal yang harus di isi oleh para calon peserta pelatihan di antaranya nama lengkap, tempat lahir, tanggal lahir, alamat, nomor telepon, agama, jenis kelamin, tinggi dan berat badan, pendidikan terakhir, program dan kejuruan yang hendak diikuti di UPT PK Singosari.

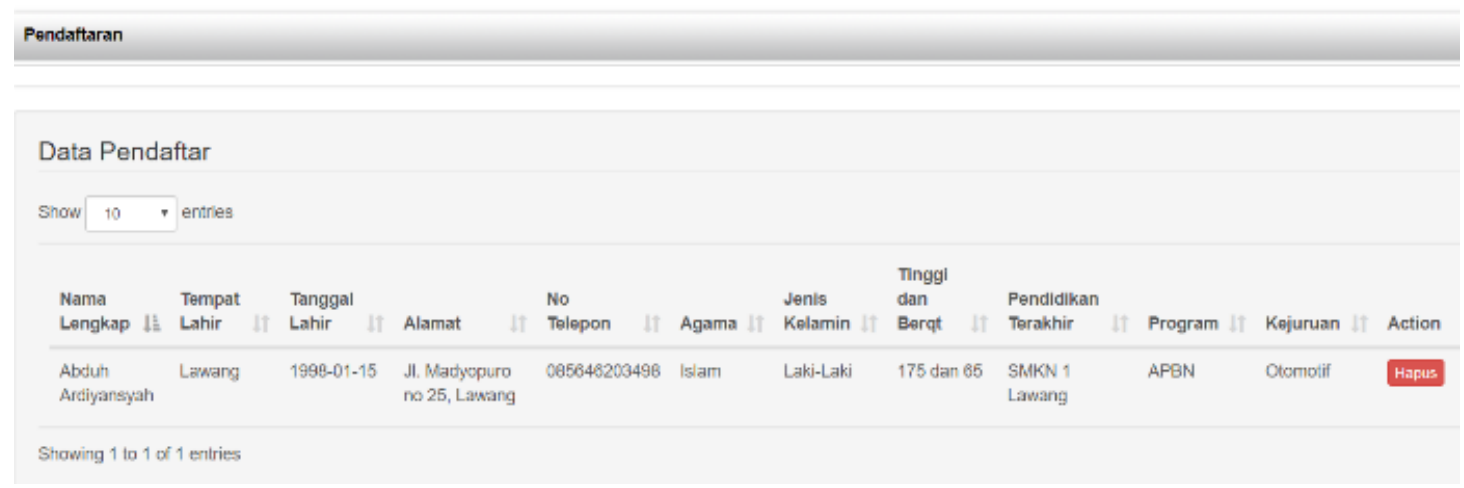

Gambar 6. Tampilan data pendaftar.

Setelah para calon peserta pelatihan melengkapi dan menyimpan formulir tersebut, data diri dari calon peserta pelatihan akan tersimpan di dalam database yang kemudian akan dicek oleh pihak admin UPT PK Singosari. Selain dapat melakukan pengecekan data calon peserta pelatihan yang masuk, admin juga dapat menghapus data tersebut apabila calon peserta pelatihan tidak melakukan prosedur pendaftaran tahap selanjutnya. Kemudian, terdapat 4 fitur/menu lain yang dapat diakses oleh admin, yaitu menu info pelatihan, info lowongan, kegiatan, dan galeri. 


\subsubsection{Menu Info Pelatihan}

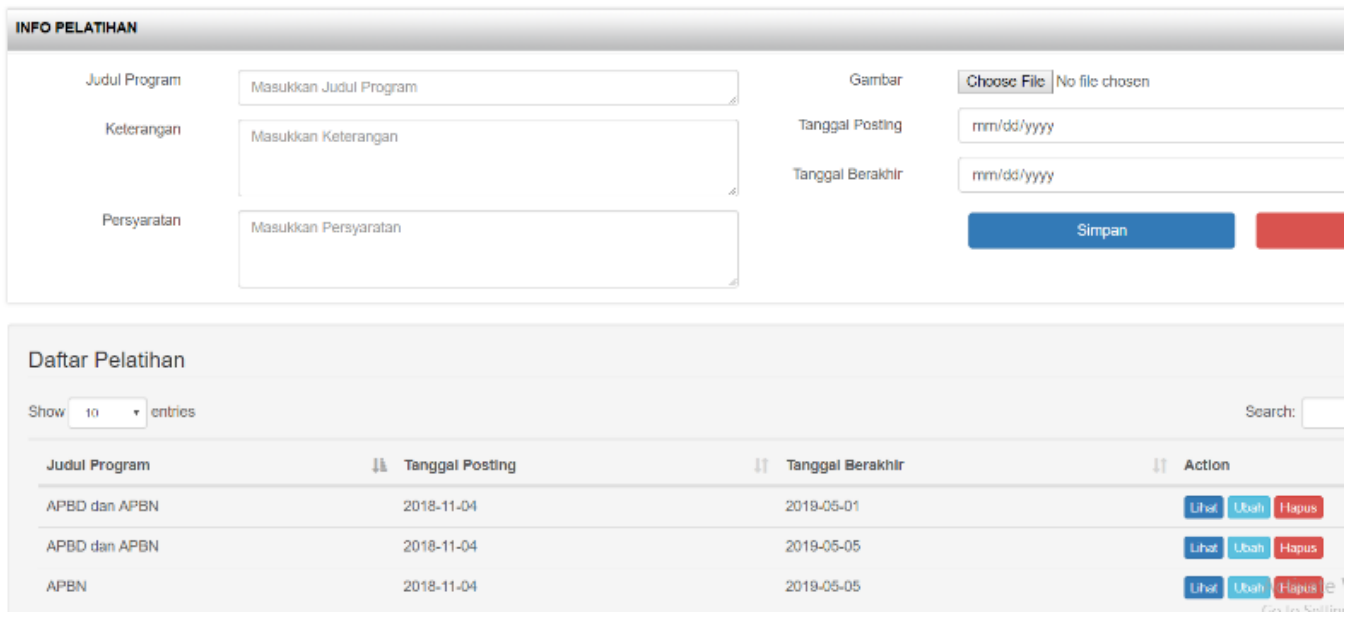

Gambar 7. Tampilan menu Info Pelatihan.

Pada Gambar 7, admin dapat melakukan penambahan terhadap data mengenai program-program pelatihan yang akan dibuka di UPT PK Singosari dengan menambahkan lampiran berupa foto brosur program pelatihan. Admin juga dapat mengubah dan menghapus data informasi program pelatihan yang sudah ditutup.

\subsubsection{Menu Info Lowongan}

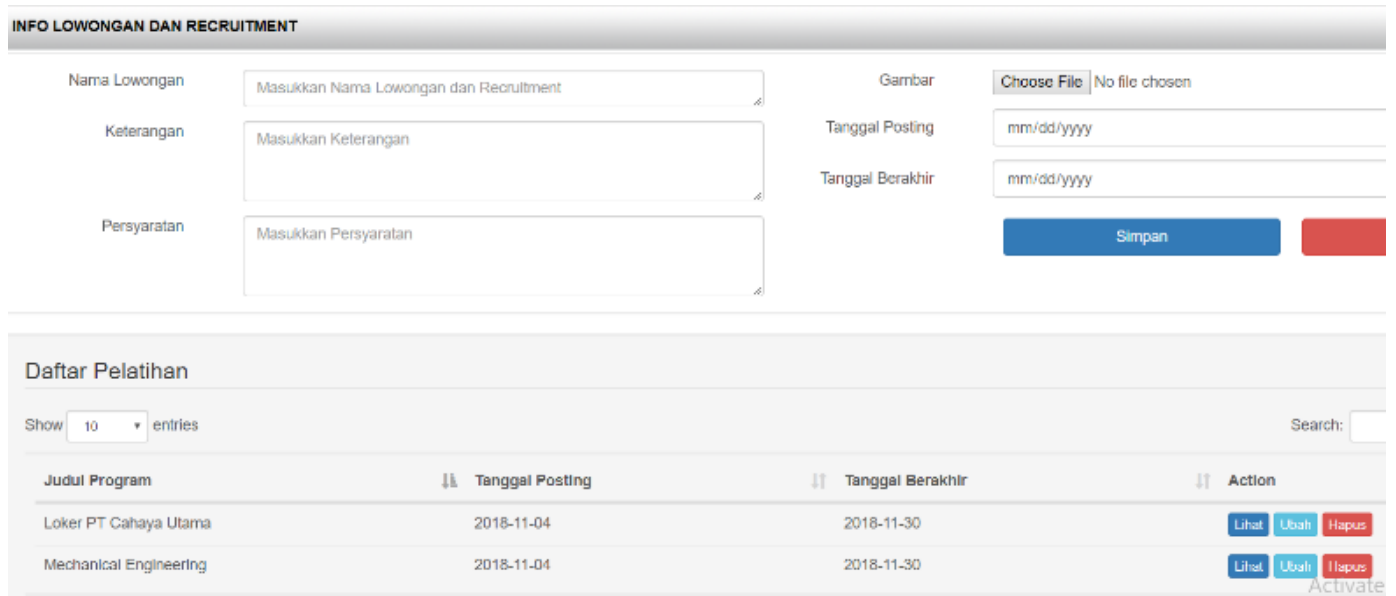

Gambar 8. Tampilan menu Info Lowongan.

Pada Gambar 8, admin dapat melakukan penambahan terhadap data mengenai informasi lowongan pekerjaan yang telah diinformasikan oleh pihak perusahaan dengan menambahkan lampiran berupa foto lowongan pekerjaan dari perusahaan yang bersangkutan. Admin juga dapat mengubah dan menghapus data informasi lowongan pekerjaan yang sudah ditutup. 


\subsubsection{Menu Kegiatan}

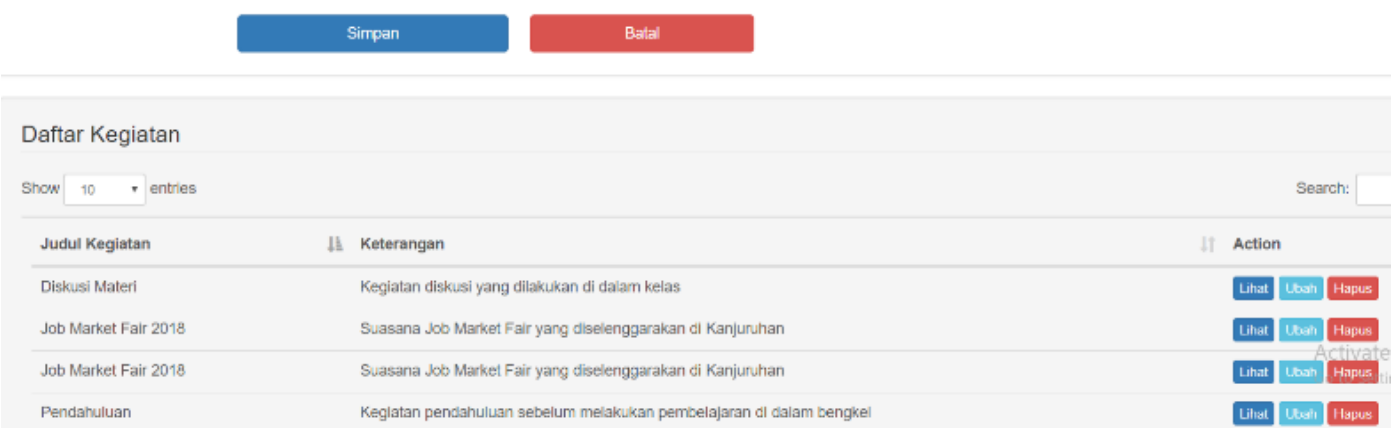

Gambar 9. Tampilan menu Kegiatan.

Pada Gambar 9, admin dapat melakukan penambahan terhadap data mengenai informasi kegiatan yang dilakukan di UPT PK Singosari dengan menambahkan lampiran berupa foto kegiatan. Admin juga dapat mengubah dan menghapus data informasi kegiatan.

\subsubsection{Menu Galeri}

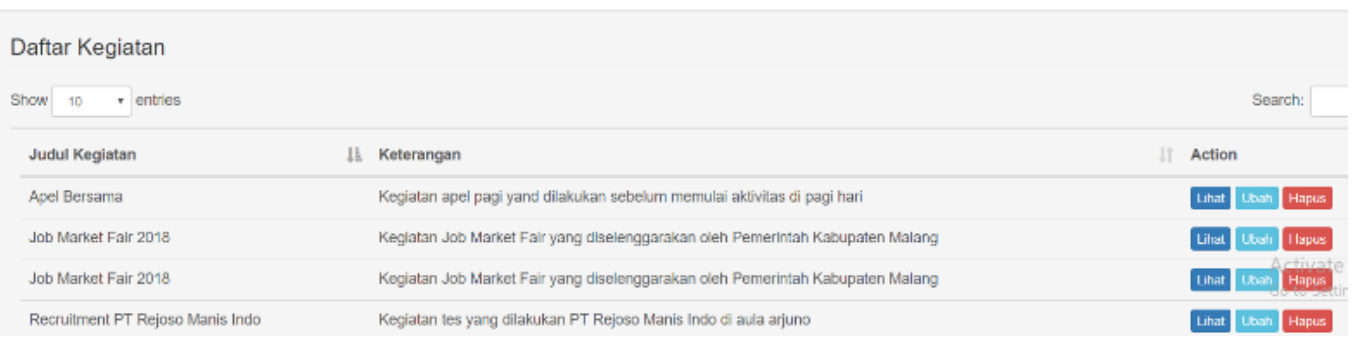

Gambar 10. Tampilan menu Galeri.

Pada Gambar 10, admin dapat melakukan penambahan terhadap data foto galeri kegiatan yang dilakukan di UPT PK Singosari beserta dengan keterangan terhadap foto tersebut. Admin juga dapat mengubah dan menghapus data foto galeri.

\section{Pengujian}

Proses pengujian yang dilakukan pada aplikasi yang dibuat menggunakan metode Pengujian black-box testing. Pengujian black-box merupakan sebuah pengujian fungsional yang menguji kondisi dalam sebuah sistem berdasarkan fungsi dari program atau sistem tersebut. Pengujian black-box merupakan pengujian yang tidak bergantung pada bagian dalam dari sistem, akan tetapi lebih mementingkan output atau keluaran dari sebuah respons sistem terhadap input yang dipilih oleh user, serta melihat kondisi eksekusinya [11]. Pengujian black-box ini mengevaluasi hanya dari tampilan luarnya (interface), fungsionalitasnya, tanpa mengetahui apa yang terjadi dalam proses detailnya (hanya mengetahui input dan output).

\subsection{Pengujian Pengisian Formulir Online}

Salah satu tahap pengujian dilakukan pada fungsi utama yaitu pengisian formulir pendaftaran seperti yang terdapat pada Tabel 2. Pengisian formulir dilakukan oleh user yang nantinya setelah dikirim akan tersimpan ke dalam database server. Data inilah yang nantinya akan digunakan oleh admin.

Tabel 2. Tabel Pengujian

\begin{tabular}{lllll}
\hline \multicolumn{1}{c}{ Deskripsi } & \multicolumn{1}{c}{$\begin{array}{c}\text { Prosedur } \\
\text { Pengujian }\end{array}$} & Masukan & $\begin{array}{c}\text { Keluaran yang } \\
\text { Diharapkan }\end{array}$ & $\begin{array}{c}\text { Hasil yang } \\
\text { Didapatkan }\end{array}$ \\
\hline $\begin{array}{l}\text { Pengujian } \\
\begin{array}{l}\text { Form } \\
\text { Pendaftaran }\end{array}\end{array}$ & $\begin{array}{l}\text { Check semua form } \\
\text { tidak diisi }\end{array}$ & $\begin{array}{l}\text { Tidak ada } \text { input } \\
\text { pada semua form }\end{array}$ & $\begin{array}{l}\text { Tampilan Form } \\
\text { peringatan harus } \\
\text { diisi }\end{array}$ & $\begin{array}{l}\text { Tampilan Form } \\
\text { peringatan harus diisi }\end{array}$ \\
\hline
\end{tabular}




\begin{tabular}{|c|c|c|c|c|c|}
\hline Deskripsi & $\begin{array}{l}\text { Prosedur } \\
\text { Pengujian }\end{array}$ & Masukan & $\begin{array}{c}\text { Keluaran yang } \\
\text { Diharapkan }\end{array}$ & $\begin{array}{c}\text { Hasil yang } \\
\text { Didapatkan }\end{array}$ & Kesimpulan \\
\hline $\begin{array}{l}\text { Pengujian } \\
\text { Form } \\
\text { Pendaftaran }\end{array}$ & $\begin{array}{l}\text { Check salah satu } \\
\text { form tidak diisi }\end{array}$ & $\begin{array}{l}\text { Tidak ada input } \\
\text { pada salah satu } \\
\text { form }\end{array}$ & $\begin{array}{l}\text { Tampilan Form } \\
\text { peringatan harus } \\
\text { diisi }\end{array}$ & $\begin{array}{l}\text { Tampilan Form } \\
\text { peringatan harus diisi }\end{array}$ & Diterima \\
\hline $\begin{array}{l}\text { Pengujian } \\
\text { Form } \\
\text { Pendaftaran }\end{array}$ & $\begin{array}{l}\text { Check salah satu } \\
\text { input tidak sesuai }\end{array}$ & $\begin{array}{l}\text { Salah satu input } \\
\text { tidak sesuai }\end{array}$ & $\begin{array}{l}\text { Tampilan Form } \\
\text { peringatan harus } \\
\text { sesuai }\end{array}$ & $\begin{array}{l}\text { Tampilan Form } \\
\text { peringatan harus } \\
\text { sesuai }\end{array}$ & Diterima \\
\hline $\begin{array}{l}\text { Pengujian } \\
\text { Form } \\
\text { Pendaftaran }\end{array}$ & Check input sesuai & $\begin{array}{l}\text { Semua input } \\
\text { sesuai }\end{array}$ & $\begin{array}{l}\text { Tampilan Data } \\
\text { berhasil masuk }\end{array}$ & $\begin{array}{l}\text { Tampilan Data } \\
\text { berhasil masuk }\end{array}$ & Diterima \\
\hline $\begin{array}{l}\text { Pengujian } \\
\text { Form } \\
\text { Pendaftaran }\end{array}$ & Hapus data & Hapus data & Data terhapus & Data terhapus & Diterima \\
\hline
\end{tabular}

\subsection{Pengiriman Data Pada Server}

Salah satu tahap pengujian juga meliputi pengiriman data pada server. Pengiriman data dari user menuju server dilakukan dengan menggunakan koneksi database pada CodeIgniter (CI) dengan memanggil alamat IP pada komputer server. Untuk mengoneksikan database maka kita perlu melakukan setting pada konfigurasi database seperti Gambar 11.

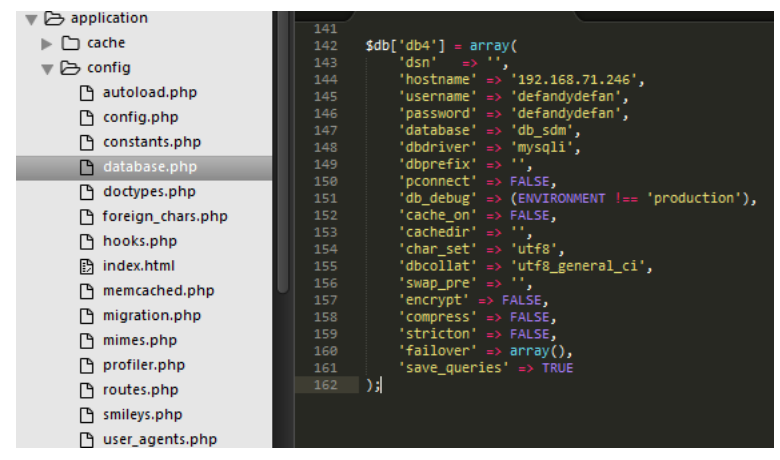

Gambar 11. Konfigurasi database.

Setelah melakukan konfigurasi database sesuai dengan alamat IP pada komputer server, maka kita juga mengisikan username dan password pada database server. Sebagai contoh kita menggunakan username dan password "defandydefan". Setelah itu kita juga melakukan inisiasi pada data model, yaitu melakukan inisiasi database sesuai konfigurasi pada halaman config. Inisiasi pada model dapat di gambarkan pada Gambar 12.

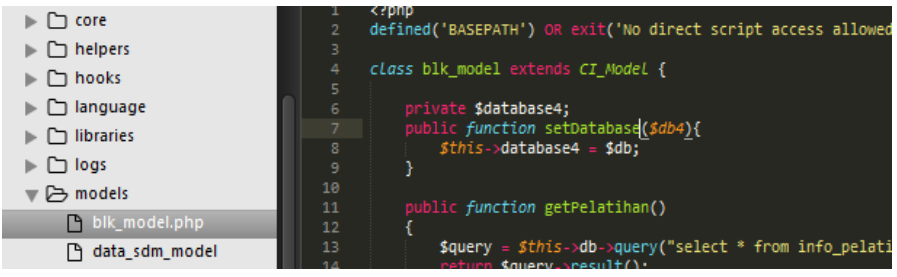

Gambar 12. Inisiasi Model.

Setelah dilakukan inisiasi maka pengiriman dan penggunaan database akan dapat terkoneksi dengan database server. Dengan terkoneksinya database maka user dapat mengirimkan data yang diisi melalui formulir dan mengirimkannya pada database server. 


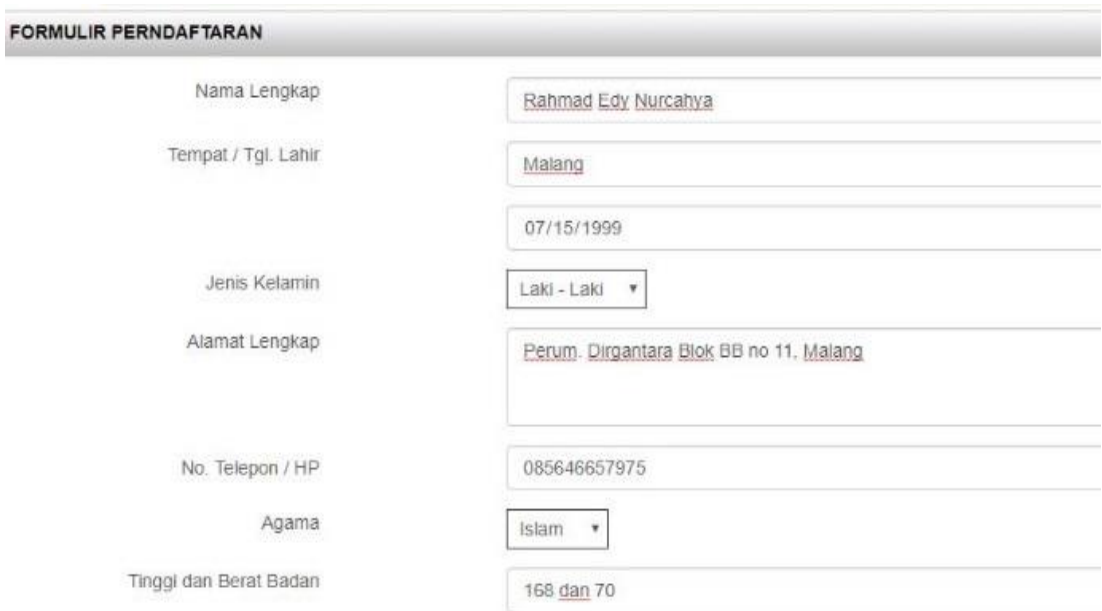

Gambar 13. Pengisian form.

Pada Gambar 13 user mencoba melakukan pengisian formulir berdasarkan identitasnya oleh user . Setiap pengisian identitas dilakukan sesuai dengan format yang telah diberikan. Setelah diisi sesuai format maka dapat dikirimkan dan disimpan ke dalam database sehingga dapat di kelola oleh admin, seperti pada Gambar 14.

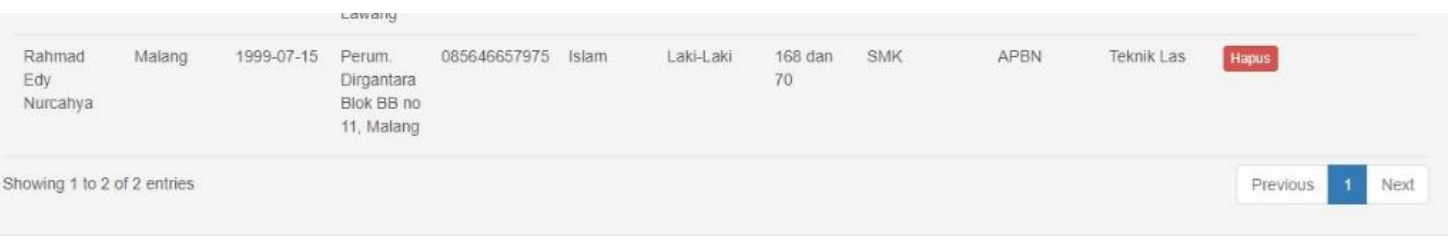

Gambar 14. Data masuk dalam database admin.

\section{Kesimpulan}

Dari pembahasan di atas dapat disimpulkan bahwa dengan adanya pembuatan sistem informasi pendaftaran dapat membantu untuk membuat kegiatan baik itu pemberian informasi dan proses pendaftaran calon peserta pelatihan menjadi lebih efektif. Hal ini dikarenakan yang semula kegiatan pemberian informasi berpusat pada papan pengumuman, kini dapat dialihkan dan dibagikan secara luas melalui media internet. Oleh karena itu siapa pun dapat mengakses informasi tersebut kapan pun dan di mana pun tanpa harus terkendala jarak. Selain itu penggunaan metode MVC (Model, View, Controller) pada aplikasi ini juga membantu proses pembuatan informasi berbasis website di UPT Pelatihan Kerja Singosari. Metode MVC dengan framework CI (CodeIgniter) dapat menampilkan konten dari website sehingga dapat terkontrol.

\section{Daftar Pustaka}

[1] F. Devy, "Penerapan Konsep Model View Controller Pada Rancang Bangun Sistem Informasi Klinik Kesehatan Berbasis Web", vol. 18, no. 2, 2018.

[2] G. Padma Arianie and N. Budi Puspitasari, "Perencanaan Manajemen Proyek Dalam Meningkatkan Efisiensi Dan Efektifitas Sumber Daya Perusahaan (Studi Kasus : Qiscus Pte Ltd),” J@ti Undip J. Tek. Ind., vol. 12, no. 3, p. 189, 2017.

[3] R. N. W, S. Romlah, and U. D. Rosiani, "Sistem Informasi Data Keuangan Laporan Akuntabilitas Kinerja Instansi Pemerintah (LAKIP) Politeknik Negeri Malang," J. Inform. Polinema, pp. 41-47, 2015.

[4] A. M. T. P. Sudarmaningtyas, "Analisis Dan Perancangan Sistem Informasi Penjualan Air Minum Pada Cv. Air Putih," Jsika, vol. 3, no. 2, pp. 1-6, 2014.

[5] P. Agus and Y. Safitri, "Pemanfaatan Sistem Informasi Perpustakaan Digital Berbasis Website Untuk Para Penulis Agus Prayitno 1) Yulia Safitri 2),” Indones. J. Softw. Eng., vol. 1, no. 1, pp. 1-10, 2015.

[6] A. Hendini, "Pemodelan UML sistem informasi Monitoring Penjualan dan stok barang," Pemodelan Uml Sist. Inf. Monit. Penjualan Dan Stok Barang (Studi Kasus Distro Zhezha Pontianak), vol. IV, no. 2, pp. 107-116, 2016. 
[7] A. R. Dewantara and L. G. Astuti, “Analisis Dan Perancangan Sistem Informasi Survei Idustri Besar Dan Sedang ( IBS ) Bulanan Badan Pusat Statistik ( BPS ) Provinsi Bali," vol. 7, no. 2, 2018.

[8] T. A. Kurniawan, "Pemodelan Use Case (UML): Evaluasi Terhadap beberapa Kesalahan dalam Praktik,” J. Teknol. Inf. dan Ilmu Komput., vol. 5, no. 1, p. 77, 2018.

[9] Pastima Simanjuntak \& Arwin Kasnady, "Analisis Model View Controller (Mvc) Pada Bahasa Php," Fak. Tek. Progr. Stud. Tek. Inform., vol. 2, no. 2, pp. 56-66, 2013.

[10] M. G. Asshokin, D. Kusbianto, P. Aji, A. Retno, and T. Ririd, "Sistem Manajemen Pengelolahan Hotel Umm Inn Berbasis Website," J. Inform. Polinema, no. 2, pp. 30-35, 2015.

[11] M. A. Fakhri, I. Aknuranda, and D. Pramono, "Implementasi Sistem Informasi Showroom Mobil ( SISMOB ) dengan Pemrograman Berbasis Objek ( Studi Kasus : UD . Tomaru Oto )," J. Pengemb. Teknol. Inf. dan Ilmu Komput. Univ. Brawijaya, vol. 2, no. 9, pp. 2967-2974, 2018. 